\title{
PENGARUH TARIF PAJAK PENGHASILAN PERUSAHAAN TERHADAP JOB CREATION
}

\section{Muhammad Romadhoni, Prani Sastiono}

Fakultas Ekonomi dan Bisnis, Universitas Indonesia (UI) Depok, Jawa Barat, Indonesia Email: romadhoni.m765@gmail.com,prani@ui.ac.id

\begin{abstract}
Abstrak
Pemerintah mengeluarkan kebijakan presumptive tax yaitu PP 46 Tahun 2013 yang berlaku bagi sektor UMKM dengan peredaran bruto tidak lebih dari 4,8 Miliar Rupiah dalam satu tahun, dengan ketentuan tarif pajak penghasilan sebesar 1 persen dari omset. Di sisi lain, sektor UMKM menyerap sebagian besar tenaga kerja di Indonesia. Penelitian ini mengestimasi apakah kebijakan PP46 Tahun 2013 di Indonesia berpengaruh terhadap penciptaan lapangan kerja (job creation) pada perusahaan sektor kecil dan menengah dengan peredaran bruto tidak lebih dari 4,8 Miliar Rupiah. Pengukuran Job Creation dan tarif efektif pajak penghasilan perusahaan menggunakan laporan SPT Wajib Pajak dari Direktorat Jenderal Pajak (DJP) selama kurun waktu 7 tahun (2010 - 2016). Estimasi dampak dilakukan dengan metode Ordinary Least Square dengan memanfaatkan variabel dummy bagi perusahaan yang menggunakan tarif pajak PP 46 serta interaksi antara variabel dummy kebijakan dan variabel tarif efektif pajak penghasilan perusahaan. Dari hasil estimasi ditunjukkan bahwa kebijakan PP 46 memiliki dampak positif signifikan pada penciptaan lapangan kerja pada perusahaan berskala kecil dan menengah.
\end{abstract}

Kata Kunci: presumptive tax; job creation; ETR

\section{Abstract}

The government of Indonesia issues presumptive tax policy by PP 46 Year 2013 for Small and Medium Enterprises (SME) sector whose turnover is not more than 4,8 Billions Rupiah per year. The rule that policy is 1 percent of income tax rate on annual turnover, not on net income. This policy can be incentive or dicinentive for SME sector. On the other hand, most employment Indonesia is in micro small and medium-sized enterprises. This study aims to examine the effect of implementation of PP46 Year 2013on the job creation in small and medium firm whose annual turnover is not more than 4.8 Billion Rupiahs. This study use Ordinary Least Square (OLS) method by utilizing dummy variable for company using PP46 tax rate and interaction between policy dummy variable and variable of effective rate of corporate income tax. From the estimation results it is shown that PP 46 policy has a significant positive impact on job creation.

Keywords: presumptive tax; job creation; ETR

$\begin{array}{ll}\text { How to cite: } & \text { Romadhoni. M \& Prani Sastiono (2021) Pengaruh Tarif Pajak Penghasilan Perusahaan Terhadap Job } \\ & \text { Creation. Syntax Literate: Jurnal Ilmiah Indonesia, 6(12) http://dx.doi.org/10.36418/Syntax- } \\ & \text { Literate.v6i12.5049 } \\ & 2548-1398 \\ \text { E-ISSN: } & \text { Ridwan Institute }\end{array}$


Received: 2021-11-20; Accepted: 2021-12-05; Published: 2021-12-20

\section{Pendahuluan}

Full employment merupakan salah satu dari tujuan ekonomi makro untuk memahami atau menyelesaikan masalah perekonomian secara keseluruhan dan sebagai alat analisis pemerintah dalam menentukan arah-arah kebijakan, selain pertumbuhan ekonomi yang optimal, pengendalian laju inflasi, peningkatan pendapatan nasional, dan distribusi pendapatan untuk mengurangi kemiskinan (Delic, Martini, Ermacora, Carraro, \& Myrta, 2005). Penciptaan lapangan kerja menjadi salah satu tantangan bagi sebagian besar negara berkembang. Berdasarkan World Development Report tahun 2013, 600 juta pekerjaan dibutuhkan di seluruh dunia untuk 15 tahun ke depan untuk menjaga employment rate pada level saat ini (Information, Technologies, \& (Program), 2012). Pemerintah, organisasi non-pemerintah dan organisasi pendonor menghabiskan sejumlah dana yang besar dengan tujuan meningkatkan penciptaan lapangan kerja (Grimm \& Paffhausen, 2015). Sektor Usaha Mikro, Kecil dan Menengah (UMKM) menjadi target intervensi kebijakan karena sebagian besar employment di negara berkembang terdapat pada sektor tersebut. (Grimm \& Paffhausen, 2015) serta (Kersten \& Stienstra, 2017) melakukan systematic review terhadap berbagai studi empiris mengenai dampak beberapa jenis intervensi yang melibatkan sektor UMKM terhadap employment pada negara berkembang, walaupun beberapa intervensi tersebut tujuan utamanya bukan penciptaan lapangan kerja. Dari 53 studi empiris yang digunakan dalam penelitian, 2 diantaranya yaitu studi empiris mengenai kebijakan presumptive tax bagi sektor UMKM di Brazil.

Presumptive tax merupakan salah satu metode perpajakan yang digunakan untuk menarik pembayaran pajak dari sektor yang sulit untuk diawasi (hard-to-tax). Tujuan dan bentuk penggunaan presumptive tax ini sangat beragam tergantung jenis kasus hard-to-tax yang akan menjadi target. Salah satu sektor hard-to-tax yang menjadi target yaitu perusahaan berskala kecil dan menengah yang tidak dapat melakukan pembukuan yang rapi namun memiliki potensi pajak (Thuronyi, 2004). Alasan penggunaan presumptive tax diantaranya kesederhanaan penghitungan; mengatasi penghindaran dan penggelapan pajak; menyediakan indikator penaksiran pajak yang objektif diharapkan dapat menciptakan keadilan sistem pajak; rebutteble presumption diharapkan dapat mendorong pengusaha untuk menjaga pembukuan dengan tertib; serta diharapkan memiliki efek insentif terhadap Wajib Pajak (Thuronyi, 2004). The political economy of presumptive systems secara garis besar menjamin bahwa beban pajak yang ditanggung cukup menguntungkan sehingga membuat metode ini menjadi menarik bagi Wajib Pajak yang menjadi target (Bird, Castelli, Malik, Frith, \& Husain, 2004). Namun, penerapan presumptive tax juga dapat merupakan disinsentif bagi Wajib Pajak, karena penghitungan pajak tidak memperhatikan besar kecilnya laba yang dihasilkan oleh Wajib Pajak, sehingga setiap Wajib Pajak yang mempunyai pendapatan yang sama belum tentu membayar jumlah pajak yang sama. 
Secara intuitif, perusahaan yang membayar pajak dengan tarif efektif yang lebih rendah akan mendorong job creation yang lebih tinggi (Leigh, 2018). Beban pajak yang tinggi dapat mengurangi profitabilitas perusahaan dan kemampuan perusahaan untuk berinvestasi dan menambah tenaga kerja (Wu, Gao, \& Gu, 2015). Salah satu kesimpulan umum mengenai corporate tax incidence yaitu jika perusahaan bersifat labor-intensive, maka beban pajak penghasilan perusahaan lebih cenderung shifting-backward terhadap tenaga kerja (Harberger, 1962). Insentif pajak bagi perusahaan yang bersifat laborintensive, akan lebih memengaruhi penggunaan tenaga kerja daripada investasi kapital perusahaan. Beberapa studi menunjukkan bahwa kebijakan berkenaan dengan tarif pajak penghasilan perusahaan memiliki pengaruh terhadap job creation dengan hasil yang bervariasi. Studi-studi tersebut telah dilakukan pada level negara bagian (Shuai \& Chmura, 2013); level county (Ljungqvist \& Smolyansky, 2014) dan level perusahaan (Leigh, 2018).

Indonesia merupakan salah satu negara berkembang dengan lebih dari 90 persen tenaga kerja berada pada sektor UMKM dan lebih dari 90 persen perusahaan merupakan kategori UMKM. Selain itu, kontribusi sektor UMKM terhadap Produk Domestik Bruto mencapai lebih dari 60 persen (Tambunan, 2008; Kementerian UKM, 2017). Sebagai salah satu upaya mendukung sektor UMKM, pada tahun 2013, pemerintah Indonesia membuat instrumen kebijakan presumptive tax berupa Peraturan Pemerintah Nomor 46 Tahun 2013 tentang Pajak Penghasilan atas Penghasilan dari Usaha yang Diterima atau Diperoleh Wajib Pajak yang Memiliki Peredaran Bruto Tertentu. Ketentuan PP46 mengatur bahwa Wajib Pajak Badan yang memiliki peredaran usaha tidak lebih dari 4,8 Miliar Rupiah diwajibkan menggunakan tarif pajak penghasilan presumptive sebesar 1 persen dari peredaran bruto, bukan berdasarkan penghasilan bersih.

Studi mengenai dampak kebijakan presumptive tax sebagai pengganti pajak penghasilan perusahaan terhadap job creation telah dilakukan. Fajnzylber, Maloney, \& Montes-Rojas (2011) melakukan studi tersebut menggunakan observasi perusahaan yang bersifat informal berdasarkan data Brazilian Survey of the Urban Informal Sector (ECINF). (Leteur, Brevan, Pavard, Silhol, \& Cherel, 2013) melakukan studi dampak kebijakan presumptive tax terhadap job creation dengan menggunakan data Brazilian Institute for Geography and Statistic (IBGE). Studi lain dilakukan oleh (Shuai \& Chmura, 2013) mencoba menganalisis dampak kebijakan penurunan tarif pajak penghasilan perusahaan terhadap job creation pada level negara bagian. Ketiga penelitian tersebut belum melibatkan variabel tarif efektif pajak penghasilan perusahaan dalam mengestimasi dampak kebijakan presumptive tax sebagai pengganti pajak penghasilan perusahaan.

Dibandingkan dengan tarif normal sebesar 12,5 persen dan 25 persen dari penghasilan bersih, PP 46 dapat merupakan insentif bagi Wajib Pajak, karena tarif yang lebih rendah, dapat pula menjadi kontraproduktif (disinsentif) bagi Wajib Pajak karena menggunakan omset sebagai dasar penghitungan pajak. Perbedaan ketentuan cara perhitungan pajak penghasilan perusahaan dari yang sebelumnya berbasis penghasilan bersih menjadi berbasis peredaran usaha dapat mempengaruhi beban pajak perusahaan. 
(Purwaningsih, 2014) melakukan studi dampak kebijakan PP 46 Tahun 2013 terhadap tarif efektif pajak penghasilan orang pribadi yang memiliki usaha sendiri (entrepreneur), dan hasilnya menunjukkan bahwa pelaksanaan PP No. 46 tahun 2013 akan merugikan Wajib Pajak Orang Pribadi jika omzetnya kecil dan jika perhitungan norma perhitungan penghasilan netto (NPPN) usaha sama atau lebih rendah dari 4,5\%.

Permasalahannya adalah:

1. Apakah kebijakan PP46 Tahun 2013 di Indonesia berpengaruh terhadap penyerapan tenaga kerja (job creation) pada perusahaan berskala kecil dan menengah?

2. Apakah pengaruh penerapan PP46 Tahun 2013 di Indonesia terhadap penyerapan tenaga kerja (job creation) terjadi melalui penurunan beban pajak penghasilan (ETR) perusahaan pada perusahaan berskala kecil dan menengah?

Kedua pertanyaan ini menjadi fokus dari penelitian ini. Oleh karena itu, tujuan penelitian ini yaitu untuk mengetahui apakah kebijakan PP46 Tahun 2013 di Indonesia berpengaruh terhadap penyerapan tenaga kerja pada perusahaan berskala kecil dan menengah; dan untuk mengetahui apakah pengaruh penerapan PP46 Tahun 2013 di Indonesia terhadap penyerapan tenaga kerja (job creation) terjadi melalui penurunan beban pajak penghasilan perusahaan berskala usaha kecil dan menengah.

\section{Metode Penelitian}

Model yang dirancang dalam penelitian ini disesuaikan dengan tujuan penelitian yaitu untuk menganalisis pengaruh kebijakan PP46 terhadap penciptaan lapangan kerja oleh perusahaan berskala kecil dan menengah. Pada penelitian untuk mengevaluasi dampak dari suatu kebijakan (impact evaluation) dapat dilakukan dengan beberapa metode. Metode yang digunakan dalam hal impact evaluation antara lain melalui Randomized Selection Method, Regression Discontinuity Design, Difference-inDifference dan Matching (Gertler, Martinez, Premand, Rawlings, \& Vermeersch, 2011). Pemilihan metode tersebut pada prinsipnya harus dapat dipisahkan antara treatment group yaitu kelompok yang terkena dampak kebijakan dan control group yaitu kelompok pembanding yang memiliki persamaan karakteristik dengan treatment group namun tidak terkena dampak kebijakan. Hal tersebut untuk mengestimasi counterfactual, yaitu hasil yang mungkin terjadi pada treatment group seandainya tidak terkena dampak kebijakan.

Pada konteks kebijakan PP 46 yang berlaku mulai Tahun 2013, pemisahan antara treatment group dan control group tidak dapat dilakukan. Hal tersebut disebabkan karena eligibilitas perusahaan yang memanfaatkan insentif pajak tergantung dari omset perusahaan yang berfluktuasi. Sedangkan apabila menggunakan perusahaan yang tidak pernah menggunakan tarif PP 46 sebagai control group akan menimbulkan kelompok pembanding yang memiliki karakteristik berbeda karena perbedaan ukuran perusahaan. Oleh karena itu, alternatif yang dapat digunakan untuk mengukur dampak kebijakan yaitu dengan menggunakan dummy variable (Baltagi, 2008). Metode kuadrat terkecil (OLS) digunakan untuk menaksir parameter dalam regresi berganda. Metode ini akan meminimumkan kesalahan (error) yang dihasilkan. Dengan demikian taksiran akan 
mempunyai variasi yang terkecil, sehingga meningkatkan ketepatan taksiran (Wooldridge, 2000).

Strategi empiris digunakan untuk membandingkan penciptaan lapangan kerja antara perusahaan yang memanfaatkan PP46 dengan perusahaan yang tidak memanfaatkan PP 46 dimana hal tersebut ditentukan berdasarkan peredaran usaha tahun sebelumnya. Selain itu, juga ditambahkan beberapa variabel yang dapat mempengaruhi penciptaan lapangan kerja oleh perusahaan. Model yang digunakan dalam penelitian ini dilakukan dengan mengadopsi model empiris yang dipakai oleh (Shuai \& Chmura, 2013) dengan tujuan untuk menangkap faktor ekternal, dalam hal ini kebijakan PP 46 Tahun 2013, terhadap penciptaan lapangan kerja oleh perusahaan (job creation). Model yang digunakan adalah sebagai berikut:

$$
\begin{aligned}
& \Delta L_{i, t, j}=\beta_{0}+\beta_{1} \times D_{-} p p 46_{i, t, j}+\beta_{2} . E T R_{i, t, j}+\beta_{3} E T R_{i, t, j}^{2}+\beta_{4} . D p p 46 * E T R_{i, t, j}+ \\
& \beta_{5} . \text { Age }_{i, t, j}+\beta_{6} . \text { Size }_{i, t, j}+\beta_{7} L_{-} \text {cost }_{i, t, j}+\beta_{8} \text { output }_{i, t, j}+\beta_{6} . \text { PDRB }_{i, t}+\delta W I L_{i}+ \\
& \mu T H N_{t}+\gamma \text { Sektor }_{i}+\varepsilon_{i, t}
\end{aligned}
$$

dengan keterangan sebagai berikut :

$\Delta L$

: kenaikan jumlah karyawan;

D_pp46 : Dummy penggunaan PP46 oleh perusahaan. Bernilai 1 apabila perusahaan memanfaatkan PP46 pada periode $\mathrm{t}$;

ETR : tarif efektif pajak penghasilan perusahaan;

$E^{2} \quad:$ kuadrat tarif efektif pajak penghasilan perusahaan;

Dpp46*ETR : variabel interaksi antara dummy PP 46 dengan ETR perusahaan;

Age : usia perusahaan;

Size : ukuran (size) perusahaan dengan menggunakan proksi revenue;

L_cost : rasio total biaya tenaga kerja dibanding total biaya;

Output $\quad$ : kapasitas produksi perusahaan dengan proksi profit usaha dalam $\mathrm{ln}$;

PDRB : Produk Domestik Regional Bruto pada level provinsi;

WIL : dummy provinsi lokasi perusahaan;

THN : dummy tahun pajak; dan

Sector : dummy kategori usaha perusahaan.

Dalam hal ini, variabel yang menjadi perhatian yaitu koefisien yang diasosiasikan dengan variabel dummy $D \_p p 46$, yang menangkap efek keseluruhan dari kebijakan PP 46. Untuk menangkap dampak kebijakan terhadap beban pajak perusahaan digunakan variabel interaksi $D p p 46^{*} E T R$. Selain itu, ditambahkan beberapa variabel kontrol yang merepresentasikan determinan yang mempengaruhi penciptaan lapangan kerja sebagaimana telah dipaparkan pada Bab II, diantaranya usia perusahaan (Age), ukuran perusahaan (Size), biaya tenaga kerja (L_cost), dan output produksi (output). Selanjutnya, teori mengasumsikan bahwa perusahaan memproduksi produk yang homogen, yang menganjurkan variabel kontrol yang menangkap pasar output yang sama dan/atau penggunaan teknologi yang sama. Dalam hal ini digunakan industry fixed 
effect, location fixed effect serta year fixed effect. Penjelasan mengenai definisi operasional variabel adalah sebagai berikut:

1. Variabel dependen dalam penelitian ini adalah penciptaan lapangan kerja oleh perusahaan atau Job Creation $(\Delta L)$ yang diidentifikasi melalui perubahan jumlah karyawan yang digunakan oleh perusahaan. Variabel ini didapatkan dengan formula jumlah tenaga kerja pada tahun t dikurangi jumlah tenaga kerja pada tahun $\mathrm{t}-1$. Hal ini telah sesuai dengan penelitian empiris sebelumnya yang dilakukan oleh (Faulk, Benninghoff, \& Holt, 2007).

2. Variabel independen pertama dalam penelitian ini adalah penggunaan tarif pajak PP 46 Tahun 2013 (D_pp46) antara tahun 2013 hingga tahun 2016. Variabel ini akan bernilai 1 (satu) apabila pada suatu tahun perusahaan menggunakan tarif PP 46 untuk menghitung pajak penghasilannya dan begitu juga sebaliknya. Tarif pajak PP 46 Tahun 2013 merupakan salah satu jenis presumptive tax atau simplifikasi peraturan perpajakan yang dapat menjadi insentif dan disinsentif bagi Wajib Pajak. Penelitian ini diharapkan memperoleh hasil estimasi bahwa Hipotesis yang digunakan yaitu perusahaan yang menggunakan PP 46 memiliki penciptaan lapangan kerja yang lebih tinggi daripada perusahaan yang tidak menggunakan PP 46. Penggunaan variabel dummy ini sesuai dengan penelitian empiris sebelumnya yang melihat dampak insentif pajak terhadap Job Creation dilakukan oleh (Faulk et al., 2007) serta (Shuai \& Chmura, 2013).

3. Variabel independen kedua adalah tarif efektif pajak penghasilan perusahaan (Tax_rate) yaitu perbandingan jumlah pajak penghasilan perusahaan yang dibayar dengan jumlah penghasilan neto Wajib Pajak Badan yang berlaku pada tahun observasi. Formula penghitungan tarif pajak efektif tersebut adalah sebagai berikut:

$$
\text { ETR }=\frac{\text { Jumlah pajak penghasilan yang dibayar }}{\text { Laba bersih }} \times 100 \%
$$

Tarif efektif pajak penghasilan perusahaan memperlihatkan berapa besar porsi penghasilan perusahaan yang digunakan untuk membayar pajak. Semakin besar tarif efektif pajak penghasilan perusahaan semakin kecil pula penghasilan setelah pajak yang dimiliki perusahaan. Diharapkan variabel tarif efektif pajak penghasilan perusahaan berkorelasi negatif dengan pertumbuhan jumlah tenaga kerja (Leigh, 2018; Ljungqvist \& Smolyansky, 2014; Shuai \& Chmura, 2013).

4. Variabel independen ketiga yang digunakan adalah usia perusahaan (Age). Haltiwanger, Jarmin, \& Miranda (2013) menjelaskan bahwa gagasan utama penggunaan variabel usia perusahaan yaitu temuan yang menekankan peran penting start-up dalam dinamika pertumbuhan pekerjaan. Mereka mendokumentasikan suatu dinamika up-or-out yang tinggi pada perusahaan-perusahaan muda. Artinya, perusahaan muda, tergantung pada kemampuan survivalnya, tumbuh lebih cepat daripada rekan-rekan mereka yang lebih dewasa. Namun, perusahaan-perusahaan muda juga memiliki kemungkinan keluar yang jauh lebih tinggi, sehingga pengurangan karyawan apabila perusahaan memutuskan keluar (out atau exit) juga 
sangat tinggi pada perusahaan muda tersebut. Lebih umum, perusahaan muda lebih mudah berubah dan menunjukkan tingkat penciptaan dan penurunan lapangan kerja yang lebih tinggi daripada rekan-rekan mereka yang lebih tua. Dalam penelitian empiris sebelumnya, usia perusahaan berkorelasi negatif dengan pertumbuhan tenaga kerja (Haltiwanger et al., 2013) sehingga hasil penelitian ini juga diharapkan demikian.

5. Variabel independen keempat yaitu ukuran perusahaan. Studi sebelumnya menganalisis pengaruh ukuran perusahaan terhadap Job Creation dengan menggunakan revenue sebagai variabel yang menunjukkan ukuran perusahaan (Leigh, 2018).

6. Variabel independen yang lain yaitu rasio biaya tenaga kerja perusahaan ( $\left.L \_c o s t\right)$. Variabel ini dihitung dengan formula:

$$
L \_c o s t=\frac{\text { Jumlah biaya tenaga kerja }}{\text { Total Biaya }} \times 100 \%
$$

Variabel (output), dengan menggunakan proksi penghasilan bersih perusahaan. Variabel ini menggunakan penghasilan bersih (dalam log). Semakin tinggi output yang diproduksi oleh perusahaan menyebabkan semakin tinggi pula penciptaan lapangan kerja oleh perusahaan.

Penelitian ini menggunakan data yang diperoleh dari Direktorat Jenderal Pajak (DJP) selaku otoritas pajak di Indonesia yang terdiri dari 7 (tujuh) tahun pajak sebagai observasi penelitian, 2010 hingga 2016, dengan jumlah observasi sebanyak 654.589. Observasi dipilih dari populasi Wajib Pajak Badan yang pernah menggunakan tarif PP46 selama periode 2013 hingga 2016 yang kemudian dilakukan filter apabila terdapat missing data karena human error, diantaranya:

- Tarif efektif kurang dari $-25 \%$ atau lebih dari $25 \%$;

- Tidak terdapat data tahun lahir atau data tahun lahir sebelum tahun 1985 atau setelah tahun 2016;

- Tidak terdapat data kode sektor usaha.

Observasi dipilih terdiri dari semua kategori usaha dan ukuran usaha Wajib Pajak Badan yang terdaftar resmi dalam administrasi DJP dan tersebar di seluruh penjuru Indonesia sehingga sampel ini dapat merepresentasikan keadaan di Indonesia.

\section{Hasil dan Pembahasan}

\section{Statistik Deskriptif}

Dalam data sampel penelitian terdapat 407.680 observasi dalam 10 kategori usaha merupakan Wajib Pajak Badan yang terdaftar di DJP. Data tersebut menunjukkan bahwa tarif efektif pajak penghasilan perusahaan memiliki variasi yang berbeda dengan tarif legal pajak yang berlaku sesuai dengan ketentuan perpajakan. Bagi perusahaan dengan peredaran usaha di atas batasan 4,8 Miliar, berlaku tarif pajak legal yang bersifat progresif sebesar 12,5 persen dan 25 persen. Berdasarkan statistik deskriptif, mulai tahun 2013 sejak berlakunya PP 46 terjadi tren penurunan 
rata-rata tarif efektif pajak penghasilan perusahaan. Jumlah total tenaga kerja yang digunakan oleh perusahaan secara garis besar mengalami kenaikan. Selain itu juga terdapat tren bahwa perusahaan yang menafaatkan tarif PP46 memiliki perumbuhan tenaga kerja yang lebih tinggi daripada perusahaan yang tidak memanfaatkan tarif PP46. Untuk mengetahui pengaruh tarif efektif pajak perusahaan dan kebijakan PP 46 terhadap pertumbuhan tenaga kerja masih perlu diperkuat dengan analisis ekonometri lebih lanjut. Grafik tren rata-rata tarif efektif pajak penghasilan perusahaan dan rata-rata pertumbuhan tenaga kerja dapat dilihat pada gambar berikut.

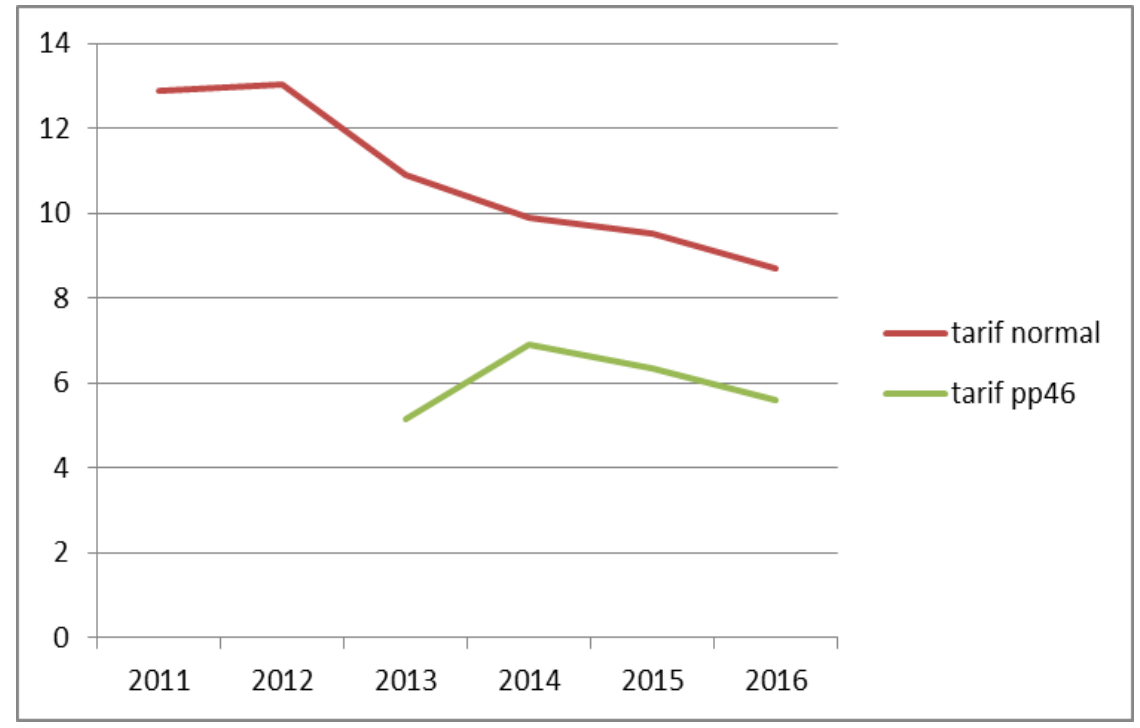

Gambar 1

Rata-rata tarif efektif pajak penghasila sebelum dan sesudah berlakunya PP 46

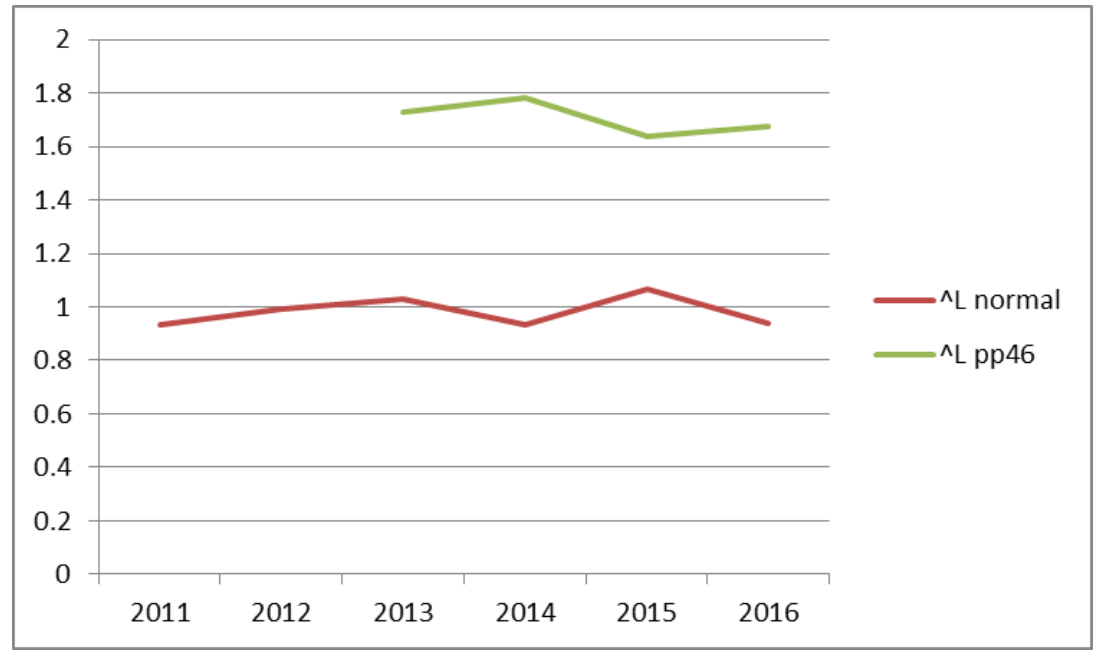

Gambar 2

Rata pertumbuhan tenaga kerja antara perusahaan yang menafaatkan dan tidak memanfaatkan PP 46 
Pengelompokan lokasi usaha wajib pajak dilakukan berdasarkan pulau dimana Wajib Pajak tersebut berlokasi. Sedangkan pengkategorian sektor usaha Wajib Pajak dilakukan berdasarkan Keputusan Direktur Jenderal Pajak Nomor KEP-321/PJ/2012 Tentang Perubahan Atas Keputusan Direktur Jenderal Pajak Nomor KEP233/PJ/2012 Tentang Klasifikasi Lapangan Usaha Wajib Pajak. Berdasarkan ketentuan tersebut, terdapat 21 (dua puluh satu) kategori usaha. Akan tetapi, karena terdapat ketidakseimbangan jumlah observasi antar sektor usaha, maka kategori usaha yang digunakan adalah sebanyak 10 sektor diantaranya sebagai berikut :

A Pertanian, kehutanan, dan perikanan

G Perdagangan besar dan eceran; reparasi dan perawatan mobil dan sepeda motor

I Penyediaan akomodasi dan penyediaan makan dan minum

$\mathrm{J} \quad$ Informasi dan komunikasi

$\mathrm{K}$ Jasa keuangan dan asuransi

M Jasa professional, ilmiah, dan teknis

$\mathrm{N}$ Jasa persewaan, ketenagakerjaan, agen perjalanan, dan penunjang usaha lainnya

$\mathrm{P}$ Jasa pendidikan

Q Jasa kesehatan dan kegiatan sosial

S Kegiatan jasa lainnya

\section{Hasil estimasi}

Penelitian ini menggunakan model estimasi Ordinary Least Square (OLS). Tabel 2 menyajikan hasil estimasi pengaruh variabel independen, yaitu rata-rata tarif efektif pajak perusahaan, terhadap kecenderungan perusahaan untuk menambah tenaga kerja. Hasil sebagaimana dapat dilihat pada tabel 2 menunjukkan bahwa perusahaan yang memanfaatkan tarif PP 46 memiliki kecenderungan menambah tenaga kerja yang lebih tinggi daripada perusahaan yang tidak memanfaatkan PP 46 pada periode yang sama. Hasil estimasi tanda korelasi dummy subsidi tarif presumptive PP 46 ini sesuai dengan hasil studi sebelumnya tentang insentif berupa penurunan tarif pajak oleh (Shuai \& Chmura, 2013); Perusahaan yang memanfaatkan PP46 cenderung memiliki pertumbuhan tenaga kerja lebih tinggi sebanyak 1 tambahan orang.

Variabel independen berikutnya, yaitu tarif efektif pajak penghasilan perusahaan memiliki pengaruh positif terhadap kecenderungan perusahaan untuk menambah tenaga kerja. Hasil ini tidak sesuai dengan teori dan sesuai dengan studi empiris sebelumnya yang dilakukan oleh (Leigh, 2018). Kenaikan 1 persen tarif efektif pajak penghasilan perusahaan terdapat kenaikan kecenderungan perusahaan untuk menambah tenaga kerja sebanyak 0,05 tambahan orang. Hasil tersebut menunjukkan hubungan yang sangat kecil, artinya tidak ada peningkatan yang signifikan.

Variabel yang menjadi perhatian selanjutnya yaitu variabel interaksi antara dummy pemanfaatan PP46 dengan tarif efektif pajak penghasilan perusahaan. Hasil estimasi menunjukkan hubungan negatif, artinya perusahaan yang memanfaatkan 
PP46 memiliki tarif efektif yang lebih rendah daripada perusahaan yang tidak memanfaatkan PP46.

Tabel 3

Hasil Estimasi OLS Model

\begin{tabular}{lccccc}
\hline Variabel & 1 & 2 & 3 & 4 & 5 \\
\hline D_pp46 & $1.280^{* * *}$ & & $1.554 * * *$ & $1.607 * * *$ & $1.675^{* * *}$ \\
\hline ETR & & $0.0402^{* * *}$ & $0.0571^{* * *}$ & $0.0533^{* * *}$ & $0.0587 * *$ \\
\hline Dpp46_ETR & & & $-0.00706^{* *}$ & -0.00296 & -0.00374 \\
\hline age & $-0.0400^{* * *}$ & $-0.0390^{* * *}$ & $-0.0372^{* * *}$ & $-0.0360^{* * *}$ & $-0.0422^{* * *}$ \\
\hline size & $0.000271^{* * *}$ & $0.000232^{* * *}$ & $0.000246^{* * *}$ & $0.000251^{* * *}$ & $0.000255^{* * *}$ \\
\hline PDRB & $-0.131^{* * *}$ & $0.0496^{* *}$ & $-0.117^{* * *}$ & $-0.198^{* * *}$ & $-0.138^{* * *}$ \\
\hline Year Fixed Effect & No & No & No & Yes & Yes \\
\hline Location Fixed Effect & No & No & No & Yes & Yes \\
\hline Industry Fixed Effect & No & No & No & No & Yes \\
\hline
\end{tabular}

Nilai standar error di dalam kurung, $* p<0,10, * * p<0,05, * * * p<0,01$.

a Tahun pajak 2011 sebagai referensi dummy.

b Kategori usaha pertanian, perkebunan, dan kehutanan sebagai referensi dummy.

c Pulau Sumatra sebagai referensi dummy

Variabel independen berikutnya, usia perusahaan, memiliki pengaruh negatif terhadap pertumbuhan tenaga kerja perusahaan. Usia perusahaan diukur dengan menggunakan selisih antara tahun berjalan dengan tahun berdiri perusahaan. Perusahaan yang telah lama berdiri memiliki tingkat efisiensi yang maksimum sehingga pertumbuhannya tidak setinggi perusahaan yang baru berdiri. Koefisien usia perusahaan ini yang bernilai negatif dan signifikan ini telah sesuai dengan penelitian empiris sebelumnya (Haltiwanger et al., 2013).

Dalam penelitian ini, variabel ukuran perusahaan diukur melalui nilai penjualan kotor (omset). Hasil estimasi menunjukkan bahwa ukuran perusahaan berkorelasi positif dan signifikan terhadap kecenderungan perusahaan menambah tenaga kerja. Hal tersebut mengimplikasikan bahwa perusahaan dengan nilai omset yang tinggi memiliki kecenderungan pertumbuhan tenaga kerja yang lebih tinggi. Pada identifikasi melalui jumlah penghasilan bruto, hasil estimasi menunjukkan bahwa setiap kenaikan $1 \%$ ukuran perusahaan (omset) menyebabkan peningkatan indikasi penggelapan pajak sekitar 0,09\%. Hasil tersebut konsisten pada percobaan pertama hingga kelima. Hasil ini tidak sesuai dengan studi empiris sebelumnya yang dilakukan oleh (Leigh, 2018) yang hanya menggunakan data sampel perusahaan besar. Haltiwanger (2013) menjelaskan dalam studinya bahwa hubungan antara ukuran perusahaan dengan pertumbuhan jumlah karyawan tidak bersifat sistematis. Hubungan dapat bersifat positif maupun negatif dan perlu dikaitkan dengan karakteristik perusahaan lain misalnya usia perusahaan. Perusahaan kecil yang baru berdiri memiliki kecenderunan yang lebih besar untuk menambah tenaga kerja.

Hasil estimasi penggunaan variabel dummy lokasi perusahaan, digunakan lokasi Pulau Sumatra sebagai dasar. Pulau Jawa, Kalimantan dan Papua memiliki kecenderungan pertumbuhan tenaga kerja yang lebih tinggi dan signifikan daripada 
pulau Sumatra sebagai dasar. Pulau lain juga menunjukkan hasil yang sama namun tidak signifikan. Hasil estimasi tersebut mengimplikasikan bahwa tren pertumbuhan tenaga kerja yang tinggi terjadi pada pulau Jawa, Kalimantan dan Papua.

Untuk variabel dummy kategori usaha, kategori usaha pertanian, perkebunan, dan kehutanan adalah sebagai referensi dasar. Pada identifikasi pertama kategori usaha Jasa persewaan dan ketenagakerjaan; Jasa pendidikan; dan Jasa kesehatan dan kegiatan sosial memiliki pertumbuhan tenaga kerja yang lebih tinggi dan signifikan. Kategori usaha lainnya bernilai lebih rendah dan memiliki signifikansi yang berbedabeda dengan kategori usaha dasar. Hasil estimasi tersebut menunjukkan bahwa pertumbuhan tenaga kerja cenderung lebih banyak terdapat pada kategori usaha jasa tersebut. Hal tersebut menunjukkan adanya tendensi pertumbuhan ekonomi pada sektor usaha jasa tersebut dibandingkan dengan sektor lain yang menarik untuk dilakukan penelitian lebih lanjut.

\section{Kesimpulan}

Hasil penelitian ini menunjukkan bahwa pemanfaatan PP46 oleh perusahaan memiliki pengaruh positif terhadap pertumbuhan penggunaan tenaga kerja. Dari segi tax subsidy, hasil ini sejalan dengan hasil studi dimana mereka menggunakan dummy taxcut policy. Sedangkan perusahaan yang memanfaatkan PP 46 mengalami penurunan tarif efektif pajak penghasilan yang signifikan Selain itu, sama dengan studi empiris sebelumnya, usia perusahaan memiliki pengaruh yang signifikan terhadap pertumbuhan tenaga kerja bahwa perusahaan yang lebih muda memiliki pertumbuhan tenaga kerja yang lebih tinggi daripada perusahaan yang sudah lama berdiri.

Hasil penelitian ini memiliki implikasi terhadap penentuan kebijakan publik yang bersifat strategis. Pemberian insentif berupa pemotongan tarif pajak penghasilan perusahaan dengan pengenaan presumptive tax yang memberi kemudahan Wajib Pajak untuk menghitung pajak penghasilannya. Sedangkan perusahaan yang memanfaatkan PP 46 mengalami penurunan tarif efektif pajak penghasilan yang signifikan artinya kebijakan PP 46 memiliki insentif efek terhadap beban pajak perusahaan. 


\section{BIBLIOGRAFI}

Acemoglu, Daron, Johnson, Simon, \& Robinson, James A. (2001). The Colonial Origins Of Comparative Development: An Empirical Investigation. American Economic Review, 91(5), 1369-1401. Google Scholar

Autio, Erkko. (2005). Creative Tension: The Significance Of Ben Oviatt's And Patricia Mcdougall's Article 'Toward A Theory Of International New Ventures.' Journal Of International Business Studies, 36(1), 9-19. Google Scholar

Baer, Douglas S., Paul, Joshua B., Gupta, Manish, \& O'keefe, Anthony. (2002). Sensitive Absorption Measurements In The Near-Infrared Region Using Off-Axis Integrated-Cavity-Output Spectroscopy. Applied Physics B, 75(2), 261-265. Google Scholar

Baltagi, B. H. (2008). Econometrics. 4th Edition. Google Scholar

Bird, Chris M., Castelli, Fulvia, Malik, Omar, Frith, Uta, \& Husain, Masud. (2004). The Impact Of Extensive Medial Frontal Lobe Damage On 'Theory Of Mind'and Cognition. Brain, 127(4), 914-928. Google Scholar

Cantor, Nancy. (1990). From Thought To Behavior:" Having" And" Doing" In The Study Of Personality And Cognition. American Psychologist, 45(6), 735. Google Scholar

Delic, D., Martini, M., Ermacora, P., Carraro, L., \& Myrta, A. (2005). First Report Of Fruit Tree Phytoplasmas And Their Psyllid Vectors In Bosnia And Herzegovina. Journal Of Plant Pathology, 87(2). Google Scholar

Dyreng, Scott D., Hanlon, Michelle, Maydew, Edward L., \& Thornock, Jacob R. (2017). Changes In Corporate Effective Tax Rates Over The Past 25 Years. Journal Of Financial Economics, 124(3), 441-463. Https://Doi.Org/10.1016/J.Jfineco.2017.04.001 Google Scholar

Fajnzylber, Pablo, Maloney, William F., \& Montes-Rojas, Gabriel V. (2011). Does Formality Improve Micro-Firm Performance? Evidence From The Brazilian Simples Program. Journal Of Development Economics, 94(2), 262-276. Google Scholar

Faulk, C. K., Benninghoff, Abby D., \& Holt, G. J. (2007). Ontogeny Of The Gastrointestinal Tract And Selected Digestive Enzymes In Cobia Rachycentron Canadum (L.). Journal Of Fish Biology, 70(2), 567-583. Google Scholar

Gertler, Paul J., Martinez, Sebastian, Premand, Patrick, Rawlings, Laura B., \& Vermeersch, Christel M. J. (2011). Impact Evaluation In Practice. In The World Bank Publications. Google Scholar

Grimm, Michael, \& Paffhausen, Anna Luisa. (2015). Do Interventions Targeted At 
Micro-Entrepreneurs And Small And Medium-Sized Firms Create Jobs? A Systematic Review Of The Evidence For Low And Middle Income Countries. Labour Economics, 32, 67-85. Google Scholar

Haltiwanger, John, Jarmin, Ron S., \& Miranda, Javier. (2013). Who Creates Jobs? Small Versus Large Versus Young. Review Of Economics And Statistics, 95(2), 347-361. Google Scholar

Harberger, Arnold C. (1962). The Incidence Of The Corporation Income Tax. Journal Of Political Economy, 70(3), 215-240. Google Scholar

Information, World Bank., Technologies, Communication, \& (Program), Infodev. (2012). Information And Communications For Development 2012: Maximizing Mobile. World Bank Publications.

Kersten, Sander, \& Stienstra, Rinke. (2017). The Role And Regulation Of The Peroxisome Proliferator Activated Receptor Alpha In Human Liver. Biochimie, 136, 75-84. Google Scholar

Leigh, Andrew. (2018). Do Firms That Pay Less Company Tax Create More Jobs? Economic Analysis And Policy, 59, 25-28. Google Scholar

Leteur, Mireille, Brevan, Claude, Pavard, Laurent, Silhol, Roger, \& Cherel, Jean Louis. (2013). Offshore Wind Farm Project Off The Coast Of Courseulles-Sur-Mer, 20 March-20 July 2013, Synthesis Of The Public Debate+ Report+ Project Manager Decision+ Project Manager File+ Synthesis. Google Scholar

Ljungqvist, Alexander, \& Smolyansky, Michael. (2014). To Cut Or Not To Cut? On The Impact Of Corporate Taxes On Employment And Income. Google Scholar

Mansury, Mica Ariana, \& Love, James H. (2008). Innovation, Productivity And Growth In Us Business Services: A Firm-Level Analysis. Technovation, 28(1-2), 52-62. Google Scholar

Musgrave, F. Kenton, Kolb, Craig E., \& Mace, Robert S. (1989). The Synthesis And Rendering Of Eroded Fractal Terrains. Acm Siggraph Computer Graphics, 23(3), 41-50. Google Scholar

Neumark, David, Wall, Brandon, \& Zhang, Junfu. (2011). Do Small Businesses Create More Jobs? New Evidence For The United States From The National Establishment Time Series. Review Of Economics And Statistics, 93(1), 16-29. Google Scholar

Oliveira, Blandina, \& Fortunato, Adelino. (2006). Firm Growth And Liquidity Constraints: A Dynamic Analysis. Small Business Economics, 27(2), 139-156. Google Scholar

Richardson, Grant, \& Lanis, Roman. (2007). Determinants Of The Variability In 
Corporate Effective Tax Rates And Tax Reform: Evidence From Australia. Journal Of Accounting And Public Policy, 26(6), 689-704. Google Scholar

Shuai, Xiaobing, \& Chmura, Christine. (2013). The Effect Of State Corporate Income Tax Rate Cuts On Job Creation. Business Economics, 48(3), 183-193. Google Scholar

Suzuki, Masaaki. (2014). Corporate Effective Tax Rates In Asian Countries. Japan And The World Economy, 29, 1-17. Google Scholar

Thuronyi, Victor. (2004). Presumptive Taxation Of The Hard-To-Tax. Contributions To Economic Analysis, 268, 101-120. Google Scholar

Wasylenko, Michael J. (1997). Taxation And Economic Development: The State Of The Economic Literature. Google Scholar

Wooldridge, Jeffrey M. (2000). A Framework For Estimating Dynamic, Unobserved Effects Panel Data Models With Possible Feedback To Future Explanatory Variables. Economics Letters, 68(3), 245-250. Google Scholar

Wu, Peng, Gao, Lei, \& Gu, Tingting. (2015). Business Strategy, Market Competition And Earnings Management: Evidence From China. Chinese Management Studies, 9(3), 401-424. Google Scholar

Yazdanfar, Ameneh, \& Ghasemi, Elham. (2011). Frequency Of Skin Cancers In Hamedan From 1991 To 2007. Google Scholar

\section{Copyright holder:}

Muhammad Romadhoni, Prani Sastiono (2021)

First publication right:

Syntax Literate: Jurnal Ilmiah Indonesia

This article is licensed under:

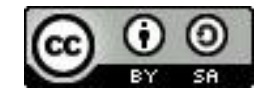

